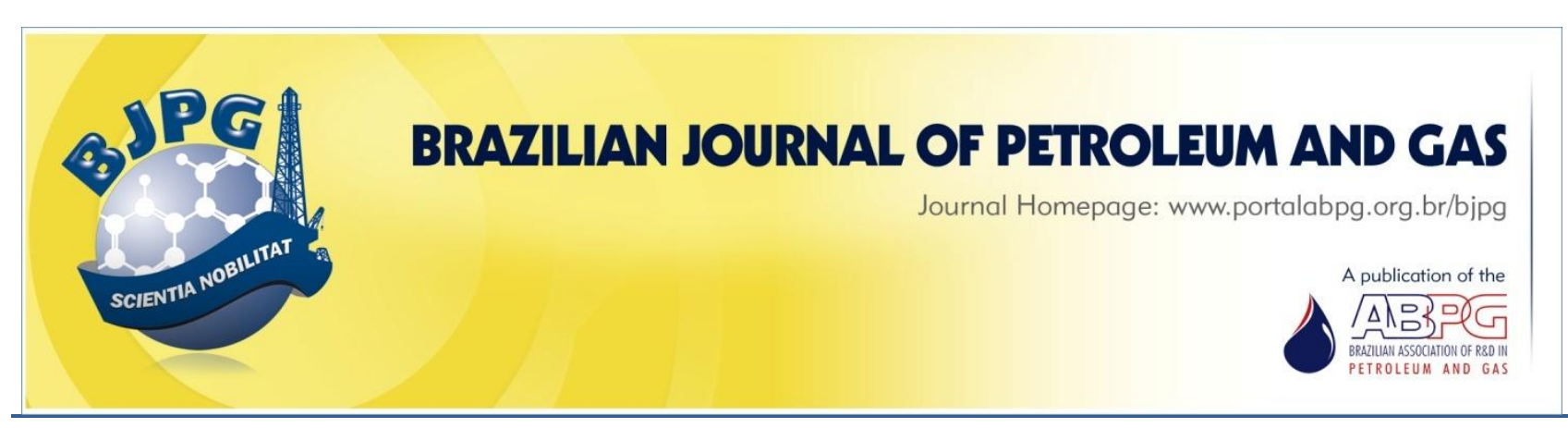

\title{
PRODUCTION OF HYDROGEN BY WATER-GAS SHIFT REACTION ON Ru/C CATALYST
}

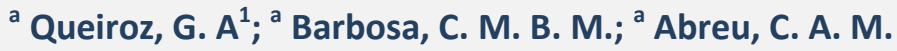 \\ ${ }^{\mathrm{a}}$ Federal University of Pernambuco (UFPE), Department of Chemical Engineering, Recife - PE - Brazil \\ Received: 30.09.2017 / Revised: 25.03.2018 / Accepted: 27.03.2018 / Published on line: 11.07.2018
}

\begin{abstract}
This work explores the catalytic performance of a $2 \%$ ruthenium carbon $(\mathrm{Ru} / \mathrm{C})$ catalyst in the low temperature water-gas shift reaction (WGSR). The catalyst synthetized was characterized with X-ray diffraction (XRD) and specific surface area (BET) methods. The gas mixture of $15 \%$ carbon monoxide + argon and water were used as reagents. The operations catalytic were performed in a fixed bed reactor over a temperature range of 453-553 K. A numerical fitting algorithm was developed for the estimation of the kinetic parameters in a power-law model for the rate velocity. At $553 \mathrm{~K}, 80 \% \mathrm{CO}$ conversion was achieved, under steady state. For the empirical rate equation, the activation energy determined from the experimental data, was $190 \mathrm{~kJ} / \mathrm{mol}$.
\end{abstract}

\section{KEYWORDS}

kinetics, low temperature, water-gas shift reaction, catalyst, Ruthenium

\footnotetext{
${ }^{1}$ To whom all correspondence should be addressed.

Address: Universidade Federal de Pernambuco, Departamento de Engenharia Química, Cidade Universitária, Avenida Prof. Moraes Rego, 1235, Recife, PE, Brasil.

ZIP Code: 50670-901 | Telephone: +55 81 2126-8901 | e-mail: germana aqueiroz@yahoo.com.br doi:10.5419/bjpg2018-0009
} 


\section{INTRODUCTION}

The WGSR is used in the production of ammonia, methanol, hydrogen, and hydrocarbons (Ratnasamy \& Wagner, 2009). Recently, there is a renewed industrial interest due to the development of fuel cell technology (Ayastuy et al., 2004; Choi \& Stenger, 2003; Saeidi et al., 2016). The process is a reversible, moderately exothermic, equilibrium limited reaction, Eq. (1). Therefore, the thermodynamics show that low temperatures favour higher $\mathrm{CO}$ conversions. However, there is a decrease in reaction rate when we apply such conditions (Mendes et al., 2010a).

$$
\mathrm{CO}+\mathrm{H}_{2} \mathrm{O} \Leftrightarrow \mathrm{CO}_{2}+\mathrm{H}_{2}
$$

$\Delta H_{298}^{0}=-41.1 \mathrm{~kJ} / \mathrm{mol}$

Iron and chrome catalysts are used in industrial processes at high temperatures (HT), operating at 593-633 K, converting the reactants up to the thermodynamically limited equilibrium. Copperbased shift catalysts at low temperature (LT), operating at $463-523 \mathrm{~K}$, are thermodynamically favoured (Ayastuy et al., 2004; Mendes et al., 2010a; Queiroz et al., 2016; Ruettinger et al., 2003; Sun et al., 2005). These industrial catalysts, when compared to noble metal catalysts, exhibit lower yields and present several industrial problems. The noble metals increase the reaction activity, eliminate the self-heating issue, and present a bifunctional behaviour due to the participation of dispersed metal and the support (Fu et al., 2003; Kalamaras et al., 2009; Panagiotopoulou, 2004; Sun et al., 2005).

The catalytic properties vary according to the type of catalytic support used (Lian et al., 2011). Thus, alumina as catalytic support is used widely in several industrial chemical processes due to the high dispersion capacity of the active phase. Although many of them are stable and resistant, there still are some technical drawbacks that need to be overcome. In recent years, active carbon has been used as a catalytic support in heterogeneous catalytic reactions. Furthermore, the presence of micropores, high surface areas, and controllable surface functionality make this material an efficient support with great abilities that are considered reliable in many industrial applications (Li \& Wu, 2009; Lian et al., 2011).
The kinetics of WGSR is thoroughly investigated within the micro-kinetic and empirical approach. The empirical models, used jointly with a computational method, seem adequate in many cases to develop a reaction rate expression. The empirical model has been studied and developed by various research groups for both high and lowtemperatures (Fu et al., 2003; Maklavany et al., 2016; Phatak et al., 2007). In this work, the activity of WGSR in low temperatures over $\mathrm{Ru} / \mathrm{C}$ catalysts was studied, and the kinetics discussed according to the empirical approach.

\section{MATERIALS AND METHODS}

\subsection{Materials}

The catalytic support used in this study was activated coal (Carbomafra S. A, Brazil), and the precursor salt was $\mathrm{RuCl}_{3} .3 \mathrm{H}_{2} \mathrm{O}$ (Sigma Aldrich, Germany). Distilled water was used in the dilution of reagents and an oven was used in the drying step.

\subsection{Preparation and characterization of the catalyst}

The $2 \% \mathrm{Ru} / \mathrm{C}$ catalysts were prepared by the impregnation method, the bulk quantity of $2 \%$ has a promoter function in the catalyst with the objective of increasing the catalytic activity and facilitating the exchange of electrons between the reactants and the catalyst. Initially, the catalytic support was pre-treated. The activated coal was washed with hot water and the soot formed was removed from the water surface. $0.56 \mathrm{~g}$ of the metal salt $\left(\mathrm{RuCl}_{3} .3 \mathrm{H}_{2} \mathrm{O}\right)$ were dissolved in $0.25 \mathrm{~L}$ distilled water; after dissolution, the catalytic support was added to the Erlenmeyer flask followed by another $0.25 \mathrm{~L}$ of distilled water, to give a total of $0.5 \mathrm{~L}$. This process took place under continuous stirring for $48 \mathrm{~h}$. Following, the solution was dried in an oven at $60^{\circ} \mathrm{C}$ for $24 \mathrm{~h}$.

The precursor was reduced in the presence of an equimolar $\mathrm{H}_{2}: \mathrm{N}_{2}$ gas mixture $\left(25 \mathrm{mLmin}^{-1}\right)$ at $400^{\circ} \mathrm{C}$, for $6 \mathrm{~h}$ (Queiroz et al., 2016). The textural and structural properties were analyzed using BET and XRD methods. The Micromeritics ASAP 2420 equipment was used for BET and the D8 advance model type (BRUKER - AXS) for the X-ray analysis. 


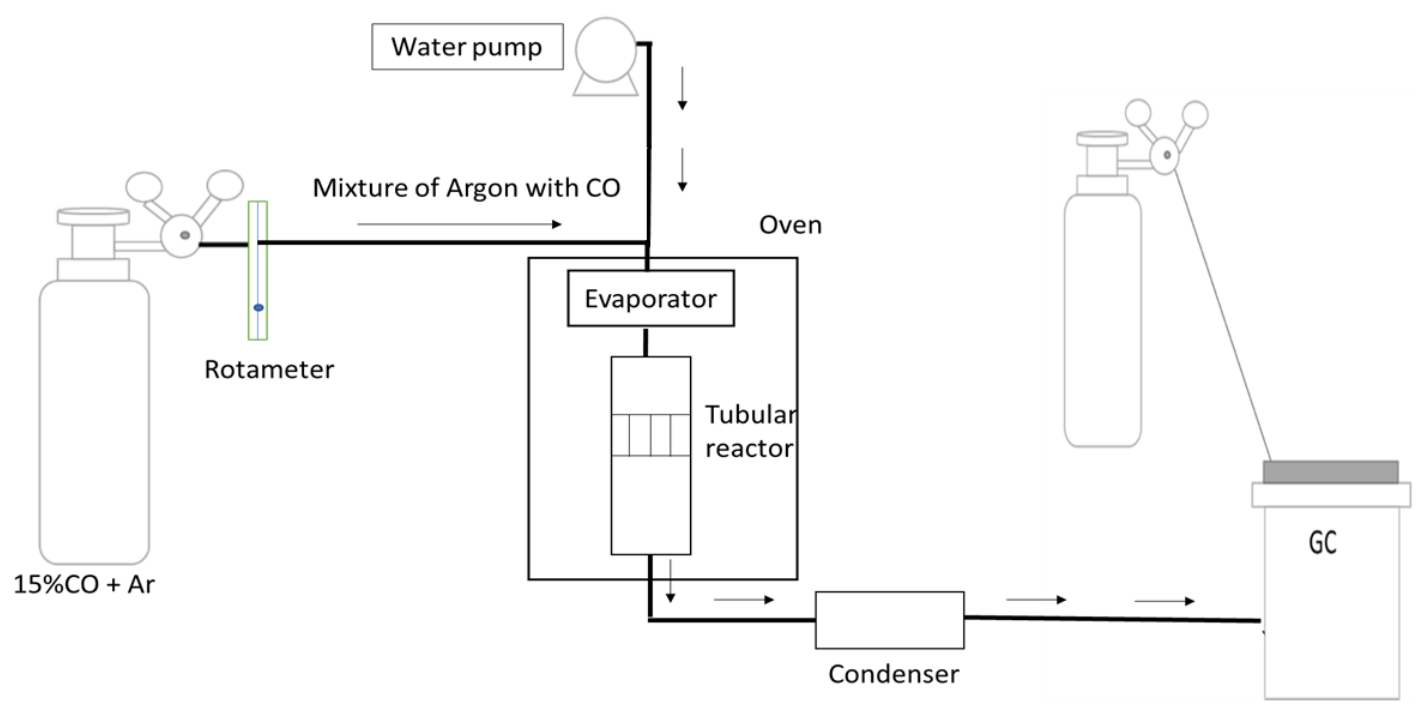

Figure 1. Experimental setup of water-gas shift reaction.

\subsection{Kinetics measures}

Kinetic rates were obtained in a fixed bed reactor with internal diameter $0.006 \mathrm{~m}$ and height $0.150 \mathrm{~m}$. The reaction run for three hours under atmospheric pressure and the temperature range was $493-553 \mathrm{~K}$. The water and $\mathrm{CO}$ flow rates were $1.33 \times 10^{-7} \mathrm{~m}^{3} / \mathrm{s}$ and $1,67 \times 10^{-7} \mathrm{~m}^{3} / \mathrm{s}$ respectively. A gas chromatograph was used as the analytic equipment provided with a Poropak $Q$ column and thermal conductivity detector (TCD), argon was used as carrier gas. A gas mixture 15\% CO in argon was used.

\subsubsection{Data analysis}

Equation 2 was obtained according to the experiment performed in the experimental unit assembled as shown in Figure 1 . In this experimental unit the water from the reagent after the reaction stays in the condenser and does not enter the column of the chromatograph. Therefore, the conversion definition equation was not considered.

$X_{C O}=\frac{1-X_{C O_{S}}}{1+X_{C O_{S}}}$

\subsection{Reaction rate}

In the empirical approach there is an absence of kinetic mechanism, the reaction rate is determined by the best fit to experimental data. Therefore, one of these models that represented the carbon monoxide conversion is show by the rate expression in Table 1 (Mendes et al., 2011; Wheeler et al., 2004).

\section{RESULTS}

\subsection{Catalyst characterization}

The results of the catalyst characterization

Table 1. Empirical rate expressions used in this work.

\begin{tabular}{llccc}
\hline Model & \multicolumn{2}{c}{ Type } & Rate expression, $\mathrm{r}$ & Ref. \\
\hline 1 & Empirical & (Power-law) & $-r_{c o}=k p_{\mathrm{CO}}^{a} p_{\mathrm{H}_{2} \mathrm{O}}^{b} p_{\mathrm{H}_{2}}^{c} p_{\mathrm{CO}_{2}}^{d}(1-\beta)$ & (Sun et al., 2005) \\
& & $\beta=\frac{P_{\mathrm{CO}_{2}} P_{\mathrm{H}_{2}}}{P_{\mathrm{CO}} P_{\mathrm{H}_{2} \mathrm{O}} K_{e q}}$
\end{tabular}




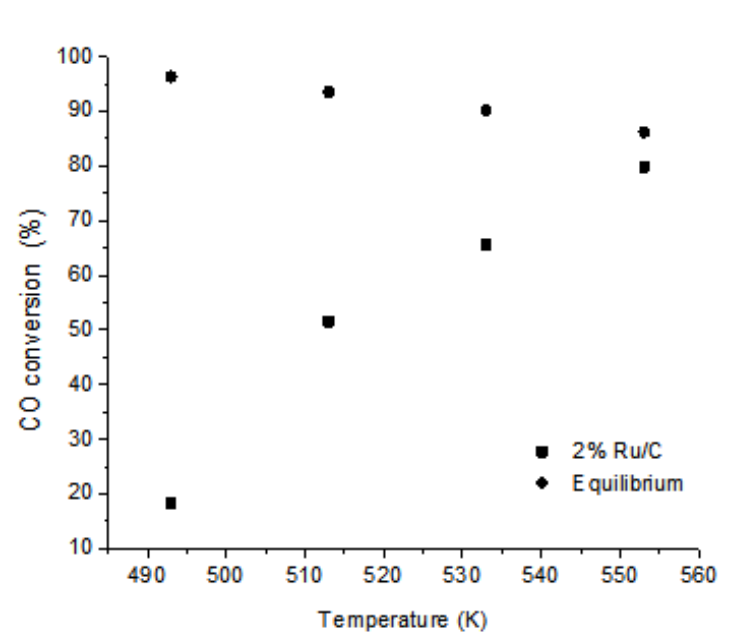

(a)

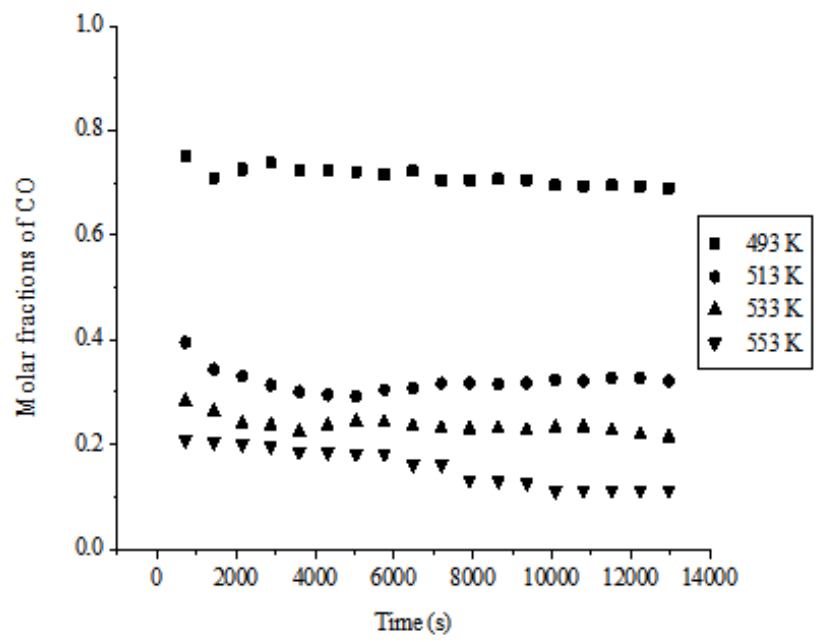

(b)

Figure 2. (a) Catalytic activity of the $2 \% \mathrm{Ru} / \mathrm{C}$ catalysts (b) Molar fractions of CO at $493,513,533$, and $553 \mathrm{~K}$.

showed that the specific surface area (BET) of the $2 \% \mathrm{Ru} / \mathrm{C}$ catalyst was $656 \mathrm{~m}^{2} \cdot \mathrm{g}^{-1}$, the pore volume was $0.24 \mathrm{~cm}^{3} \cdot \mathrm{g}^{-1}$, and the mean pore size was $13 \AA$. The XRD pattern showed characteristic peaks of the support centred on the $2 \theta$ Bragg angles at $10^{\circ}$ and $80^{\circ}$, and the presence of metal ruthenium phases with an intensities of $37.1^{\circ}, 46^{\circ}$ and $67.5^{\circ}$. The sample of $2 \% \mathrm{Ru} / \mathrm{C}$ showed an absence of crystallinity of the support, typical characteristic of an amorphous material.

\subsection{Water-gas shift reaction}

The experimental measurements of carbon monoxide conversion versus temperatures (453$553 \mathrm{~K}$ ) are shown in Figure 2a. At $493 \mathrm{~K}$ the Ru/C catalyst already exhibits a catalytic activity yielding a CO conversion of $18 \%$, and at $553 \mathrm{~K}$ the $\mathrm{CO}$ conversion reached $80 \%$, close to equilibrium conversion. Figure $2 \mathrm{~b}$ shows the molar fraction of $\mathrm{CO}$ at the exit stream, indicating that the $\mathrm{CO}$ concentration is stable, reaching the steady state after three hours. These tests were carried out for approximately $4 \mathrm{~h}$ for a temperature range of 453$553 \mathrm{~K}$ using a feed gas with $11.36 \% \mathrm{CO}, 22.72 \%$ $\mathrm{H}_{2} \mathrm{O}$, and $66.8 \% \mathrm{Ar}$. In the studied flow range, no limitations were observed on the external mass transfer. The operations had catalytic control during the entire studied time. All the results were read using the chromatograph and the computer.

\subsection{Kinetics}

Experimental reaction rates were obtained from the experimental runs, with power-law models selected to fit the data. To estimate the temperature dependence of the reaction rate, the kinetic constant $(k)$ was expressed by the Arrhenius equation $\left(k=k_{0} \exp (-E / R T)\right)$. The kinetic parameters as the pre-exponential factor $\left(k_{0}\right)$ and activation energy (Ea) along with the concentration exponents (a, b, c, d) were determined by Levenberg-Marquardt nonlinear regression algorithm (LSQNONLIN) as shown elsewhere (Choi \& Stenger, 2003; Mendes et al., 2010a; Sun et al., 2005). Runge-Kutta integration method was used to solve the mass balance equation. The parameters were found by an optimization program, where the objective function to be mininimized was the sum of squared residuals:

$\underset{\text { Parameters }}{\operatorname{Minimize}}\left(\sum_{i=1}^{N}\left(n e_{\mathrm{CO}_{i}}-n c_{\mathrm{CO}_{i}}\right)^{2}\right)$

Where $\mathrm{i}$ is the experiment number; $n e_{c o, i}$ and $n c_{c o, i}$ the experimental and calculated molar flow rates of $\mathrm{CO}$ at the reactor outlet in $\mathrm{mol} / \mathrm{h}$, respectively (Choi \& Stenger, 2003).

After treating the experimental data with the developed algorithm, in two and four temperatures simultaneously, the estimated value of the activation energy was $190 \mathrm{~kJ} / \mathrm{mol}$ and that of $\mathrm{k}_{0}$ was 41.59. The reaction order (related to the exponent of the components concentration) were $a=1.1$, $b=0.53, c=0, d=0$, corresponding to $\mathrm{CO}, \mathrm{H}_{2} \mathrm{O}, \mathrm{CO}_{2}$, $\mathrm{H}_{2}$, respectively. Activation energy values found in the literature are listed in Table 2; furthermore, 
Table 2. Comparison parameters for empirical expressions with different catalysts.

\begin{tabular}{|c|c|c|c|c|c|c|}
\hline Catalysts & a & b & c & d & $\begin{array}{c}E \\
\left(\mathrm{~kJ} \cdot \mathrm{mol}^{-1}\right)\end{array}$ & Ref. \\
\hline $2 \% \mathrm{Pt} / \mathrm{TiO}_{2}$ & 0.31 & 0.58 & -0.64 & -0.02 & 57 & (Panagiotopoulou, 2004) \\
\hline $40 \% \mathrm{CuO} / \mathrm{ZnO} / \mathrm{Al}_{2} \mathrm{O}_{3}$ & 1.0 & 1.40 & -0.70 & -0.9 & 87 & (Ovesen et al., 1992) \\
\hline $1 \% \mathrm{Pt} / \mathrm{Al}_{2} \mathrm{O}_{3}$ & 0.06 & 1.00 & -0.44 & -0.1 & 68 & (Phatak et al., 2007) \\
\hline $10 \% \mathrm{Cu} / \mathrm{Al}_{2} \mathrm{O}_{3}$ & 0.30 & 0.38 & - & - & 56 & (Grenoble et al.,1981) \\
\hline $2 \% \mathrm{Ru} / \mathrm{C}$ & 1.10 & 0.53 & - & - & 190 & Current work \\
\hline
\end{tabular}

they are compared to that of copper catalysts, which are used by the industry.

\section{DISCUSSION}

\subsection{WGS catalytic activity and effect of thermodynamics}

The CO conversion reaches a maximum of $30 \%$ for temperatures below $513 \mathrm{~K}$. The best activity was observed at the temperatures of $553 \mathrm{~K}$ because it achieved a conversion of almost $80 \%$. Conversions close to equilibrium were attained at high temperatures, and no methane was detected during the experiments. The simultaneous analysis of the effect of catalytic activity vs. stability showed that $\mathrm{Ru} / \mathrm{C}$ catalysts could be a good choice at mild temperatures due to the high activity and stability performance. In the literature, the maximum temperature to avoid the sintering effect is $573 \mathrm{~K}$. The experiments show that the catalyst was not deactivated for 3 hours (Mendes et al., 2010b). As shown in Figure $2 b$, all runs evolved to a stationary regime, regardless of the operational conditions. However, the evolution of the output composition shows that there is a higher hydrogen production and $\mathrm{CO}$ consumption at higher temperatures, during the water-gas shift process.

According to Ladebeck and Wagner (2003), from a thermodynamic perspective, the efficiency of the WGSR is maximized at low temperatures and excess steam. However, the catalysts available today are kinetically limited when it is desired to achieve a high CO conversion at low temperatures. Thus, to obtain a conversion of about $100 \% \mathrm{CO}$, as desired for the use of hydrogen in fuel cells, an increase of the reaction temperature is required to favor the activity of the catalyst.

\subsection{Empirical rate expressions}

The power law rates of low temperature catalysts for different conditions was investigated by Choi and Stenger, (2003). A good review for noble metal catalysts can be found in the work of Grenoble, Phatak, and Wheeler (Grenoble et al., 1981; Phatak et al., 2007; Wheeler et al., 2004). Podolski and Kim (1974) showed that power-law models reproduced their experimental data. Keiski et al. (1996) provided an expression for the hightemperature shift reaction. Recently, Adams and Barton (2009), using different models available in the literature, introduced a correction factor for porosity, to model a heterogeneous reactor. In this study the value of activation energy using the $2 \% \mathrm{Ru} / \mathrm{C}$ catalyst was $190 \mathrm{~kJ} / \mathrm{mol}$ using the power law rates. This value $(190 \mathrm{~kJ} / \mathrm{mol})$ is bigger than the results reported in the literature (see Table 2). According to literature the value of the activation energy varies from one chemical reaction to another and the activation energy is a way of identifying reaction pathways. Thus, a greater activation energy indicates a lower probability of the reaction to occur. This result indicates that there was a low catalytic activity, which may be justified by differences in the technique used in preparing the material or differences in the experimental conditions used to carry out the reaction. Gurrath et al. (2000) also studied activated carbon as catalytic support for several catalysts and noted that the type of treatment change the performance of the global response significantly, inhibiting or increasing the occurrence of undesired reactions. The authors realized that significant variations in reduction profiles thermoprogrammed (TPR) of the palladium were depending on the material and the method of preparation in conjunction with the physical and chemical properties of the carrier. 


\section{CONCLUSIONS}

The activity of the Ru/C catalyst was tested in the water-gas shift reaction at low temperatures with the aim of producing hydrogen and converting carbon monoxide. Processing tests showed approximately $80 \%$ of $\mathrm{CO}$ conversion at $553 \mathrm{~K}$. The kinetic parameters were found with the algorithm developed. The empirical rate equation and experimental data were tested resulting in an activation energy value of $190 \mathrm{~kJ} / \mathrm{mol}$. Reaction orders were 0.53 and 1.1 for $\mathrm{CO}$ and $\mathrm{H}_{2} \mathrm{O}$, respectively. The value of activation energy was 2-3 times higher than the value found in the literature meaning that there was a low catalytic activity. The catalytic system tested showed that ruthenium and coal activated supports can achieve a better conversion at mild temperatures. Also, the best way to improve the catalytic performance of this material is to study the best techniques to prepare this catalyst and the best experimental conditions.

\section{ACKNOWLEDGMENTS}

The authors of this work would like to recognize the Federal University of Pernambuco, PRH-28, Ministry of Science and Technology, FINEP Innovation and Research for the support provided.

\section{REFERENCES}

Adams, T. A.; Barton, P. I. A dynamic twodimensional heterogeneous model for water gas shift reactors. International Journal of Hydrogen Energy, v. 34(21), p. 8877-8891, 2009.

https://doi.org/10.1016/i.ijhydene.2009.08.045

Ayastuy, J. L.; Gutierrez-Ortiz, M. A.; GonzalezMarcos, J. A.; Aranzabal, A.; Gonzalez-velasco, J. R. Kinetics of the Low-Temperature WGS Reaction over a $\mathrm{CuO} / \mathrm{ZnO} / \mathrm{Al}_{2} \mathrm{O}_{3}$ Catalyst. Industrial \& Engineering Chemistry Research, v. 44(1), p. 4150, 2004. https://doi.org/10.1021/ie049886w

Choi, Y.; Stenger, H. G. Water gas shift reaction kinetics and reactor modeling for fuel cell grade hydrogen. Journal of Power Sources, v. 124(2), p. 432-439, 2003. https://doi.org/10.1016/S0378$\underline{7753(03) 00614-1}$
Fu, Q.; Kudriavtseva, S.; Saltsburg, H.; FlytzaniStephanopoulos, M.; Gold-ceria catalysts for lowtemperature water-gas shift reaction. Chemical Engineering Journal, v. 93(1), p. 41-53, 2003. https://doi.org/10.1016/S1385-8947(02)00107-9

Grenoble, D. C.; Estadt, M. M.; Ollis, D. F. The chemistry and catalysis of the water gas shift reaction. Journal of Catalysis, v. 67(1), p. 90-102, 1981. https://doi.org/10.1016/0021-9517(81)90263-3

Gurrath, M.; Kuretzky, T.; Boehm, H. P.; Okhlopkova, L. B.; Lisitsyn, A. S.; Likholobov, V. A. Palladium catalysts on activated carbon supports: Influence of reduction temperature, origin of the support and pretreatments of the carbon surface. Carbon, v. 38(8), p. 1241-1255, 2000. https://doi.org/10.1016/50008-6223(00)00026-9

Kalamaras, C. M.; Panagiotopoulou P.; Kondarides D. I.; Efstathiou, A. M. Kinetic and mechanistic studies of the water-gas shift reaction on Pt/TiO ${ }_{2}$ catalyst. Journal of Catalysis, v. 264(2), p. 117-129, 2009.

https://doi.org/10.1016/i.jcat.2009.03.002

Keiski, R. L.; Salmi,T.; Niemistö, P.; Ainassaari, J.; Pohjola, V. J. Stationary and transient kinetics of the high temperature water-gas shift reaction. Applied Catalysis A: General, v. 137(2), p. 349-370, 1996. https://doi.org/10.1016/0926-860X(95)00315-0

Ladebeck, J. R.; Wagner, J. P. Catalyst development for water-gas shift. In: Vielstich, W.; Lamm, A.; Hubert, A. Handbook of Fuel Cells Fundamentals, Technology and Applications. England: John Wiley \& Sons, Ltd, v. 3, p. 190-201, 2003.

$\mathrm{Li}, \mathrm{J}$; $\mathrm{Wu}, \mathrm{E}$. Adsorption of hydrogen on porous materials of activated carbon and zeolite $\mathrm{NaX}$ crossover critical temperature. The Journal of Supercritical Fluids, v. 49(2), p. 196-202, 2009. https://doi.org/10.1016/i.supflu.2008.12.015

Lian, Y.; Xiao R. F.; Fang W.;Yang Y. Potassiumdecorated active carbon supported Co-Mo-based catalyst for water-gas shift reaction. Journal of Natural Gas Chemistry, v. 20(1), p. 77-83, 2011. https://doi.org/10.1016/S1003-9953(10)60154-5

Maklavany, D. M.; Shariati, A.; Roozbehani, B.; Nikou, M. R. K.; Kinetic modeling of low temperature Water-Gas Shift reaction using gPROMS. American Journal of Oil and Chemical Technologies, v. 4(2), p. 1-11, 2016. 
Mendes, D.; Chibante, V.; Mendes, A.; Madeira, L. M. Determination of the low-temperature watergas shift reaction kinetics using a cu-based catalyst. Industrial and Engineering Chemistry Research, v. 49(22), p. 11269-11279, 2010a.

https://doi.org/10.1021/ie101137b

Mendes, D.; Chibante, V.; Zheng, J; Tosti, S.; Borgognoni, F.; Mendes, A.; Madeira, L. M. Enhancing the production of hydrogen via watergas shift reaction using $\mathrm{Pd}$-based membrane reactors. International Journal of Hydrogen Energy, v. 35(22), p. 12596-12608, 2010b. https://doi.org/10.1016/i.ijhydene.2010.07.159

Mendes, D.; Sa, S.; Tosti, S.; Sousa, J.M.; Madeira, L. M.; Mendes, A. Experimental and modeling studies on the low-temperature watergas shift reaction in a dense $\mathrm{Pd}-\mathrm{Ag}$ packed-bed membrane reactor. Chemical Engineering Science, v. 66, p. 2356-2367, 2011.

https://doi.org/10.1016/i.ces.2011.02.035

Ovesen, C. V.; Stolze, P.; Nørskov, J. K.; Campbell C. T. A kinetic model of the water gas shift reaction. Journal of Catalysis, v. 134(2), p. 445-468, 1992. https://doi.org/10.1016/00219517(92)90334-E

Panagiotopoulou, P.; Kondarides, D. I. Effect of morphological characteristics of $\mathrm{TiO}_{2}$-supported noble metal catalysts on their activity for the water-gas shift reaction. Journal of Catalysis, v. 225, p. 327-36, 2004.

https://doi.org/10.1016/j.jcat.2004.04.030

Phatak, A. A.; Koryabkina, N.; Rai, S.; Ratts, J. L.; Ruettinger, W.; Farrauto, R.J.; Blau, G. E.; Delgass, W. N.; Ribeiro, F.H. Kinetics of the water-gas shift reaction on Pt catalysts supported on alumina and ceria. Catalysis Today, v. 123(1-4), p. 224-234, 2007. https://doi.org/10.1016/i.cattod.2007.02.031
Podolski, F. W; Kim G. Y. Modeling the WaterGas Shift Reaction. Industrial \& Engineering Chemistry Process Design and Development, v. 13(4), p. 415-421, 1974.

https://doi.org/10.1021/i260052a021

Queiroz, G. A.; Barbosa, C. M. B. M.; Abreu, C. A. $M$. Low-temperature Water-Gas Shift reaction with $\mathrm{Ru} / \mathrm{TiO}_{2}$ and $\mathrm{Ru} / \mathrm{Al}_{2} \mathrm{O}_{3}$ catalysts. Brazilian Journal of Petroleum and Gas, v. 10(3), p. 135-144, 2016. https://doi.org/10.5419/bjpg2016-0011

Ratnasamy, C.; Wagner, J. P. Water Gas Shift Catalysis. Catalysis Reviews: Science and Engineering, v. 51(3), p. 325-440, 2009. https://doi.org/10.1080/01614940903048661

Ruettinger, W.; llinich, O.; Farrauto, R. J. A new generation of water gas shift catalysts for fuel cell applications. Journal of Power Sources, v. 118(12), p. $61-65,2003$. https://doi.org/10.1016/S03787753(03)00062-4

Saeidi, S.; Fazlollahic, F.; Najarid, S.; Iranshahib, D.; Klemeše, J. J.; Baxterf, L. L. Hydrogen Production: Perspectives, Separation with special emphasis on Kinetics of WGS Reaction: A state-ofthe-art review. Journal of Industrial and Engineering Chemistry, v. 49, p. 1-25, 2016. https://doi.org/10.1016/i.jiec.2016.12.003

Sun, J.; DesJardins, J.; Buglass, J.; Liu, K. Noble metal water gas shift catalysis: Kinetics study and reactor design. International Journal of Hydrogen Energy, v. 30(11), p. 1259-1264, 2005. https://doi.org/10.1016/i.ijhydene.2005.02.013

Wheeler, C.; Jhalani, A.; Klein, E. J.; Tummala, S.; Schmidt, L. D. The water-gas-shift reaction at short contact times. Journal of Catalysis, v. 223(1), p. 191-199, 2004. https://doi.org/10.1016/i.jcat.2004.01.002 